\title{
Elementary Education and Children's Lives during The Second World War in Finland
}

\author{
Satu Uusiautti (Corresponding author) \\ Faculty of Education, University of Lapland \\ PO Box 122, 96101 Rovaniemi, Finland \\ Tel: 358-484-4167Ｅ-mail: satu@uusiautti.fi
}

\begin{abstract}
Merja Paksuniemi
Faculty of Education, University of Lapland

PO Box 122, 96101 Rovaniemi, Finland

E-mail: Merja.Paksuniemi@rovaniemi.fi
\end{abstract}

Kaarina Määttä

Faculty of Education, University of Lapland

PO Box 122, 96101 Rovaniemi, Finland

Tel.358-400-696-480Ｅ-mail: Kaarina.Maatta@ulapland.fi

Received: Dec. 3, 2012 Accepted: December 21, 2012 Published: February 1, 2013

doi:10.5296/jse.v3i1.2847 URL: http://dx.doi.org/10.5296/jse.v3i1.2847

\begin{abstract}
During the Second World War, Finland fought twice against Russia and then against Germany. Except for some exceptions, children's everyday life and living surroundings changed dramatically because of war. This study provides a multidimensional picture of the war time happenings in Finland regarding elementary education. This study analyzed how elementary education was arranged during the Second World War in Finland and how war children described their life during the war. The data comprised former war-children's memories $(\mathrm{N}=13)$ and supplementary archival sources and carefully selected, relevant research literature of the time of Second World War in Finland. The archival sources included letter copies and minutes of teachers' meetings. The study showed that the patriotic ideals and
\end{abstract}


strict demands on decency and industry were a salient, unquestionable part of children's practical lives in the war-time Finland.

Keywords: Elementary education, Second World War, Memories, Finland, War children 


\section{Introduction}

Germany tore into Poland on the 1st of September 1939 due to which France and Great Britain declared war on Germany two days later. The Second World War had started. The risk of war concerned Finland, too, and the situation of foreign policy with the Soviet Union grew tense. During the Second World War, Finland fought the following Wars: The Winter War (30 November 1939-13 March 1940) was military conflict between the Soviet Union and Finland which began with a Soviet offensive two months after the start of World War II and the Soviet invasion of Poland. The Winter War ended on the Moscow Peace Treaty. The Continuation War (25 June 1941-19 September 1944) was the second war against the Soviet Union. The Lapland War (September 1944-April 1945) was fought between Finland and Nazi Germany in Finland's northernmost Lapland Province.

How were children educated during the war time? There are a few Finnish studies of children of war (Kavén, 2010, 2011; Knuuttila \& Levola, 2000; Räsänen, 1988) but those focusing on elementary education during the war time are scarcer (Hopkins, 1989; Nurmi, 1989; Paksuniemi, 2009; Syväoja, 2007). The target period of this study is the war time in 19391945 in Finland. Except for some exceptions, children's everyday life and living surroundings changed dramatically because of war (Latvala, 2006): Fathers went to the front and mothers were busy with daily chores and serving the nation. Many families had to leave their homes to find only home ruins at the time of their return. Some children were sent to abroad without their parents and some of them returned but not all. Some children were orphaned as one or both parents died during the war. (Kavén, 2010, 2011; Knuuttila \& Levola, 2000; Räsänen, 1988). In Finland, over 30,000 women were widowed and 50,000-60,000 children were orphaned (Häikiö, 1996, Salmi, 1986). Mothers were responsible for rearing because fathers were at the front (e.g., Kemppainen, 2006).

This study provides a multidimensional picture of the war time happenings in Finland regarding elementary education. On the one hand, the official records and policies are described. On the other hand, the reality is revealed through the memories narrated by those who experienced the war and school during the dramatic era. As a conclusion, we will discuss how the patriotic ideals and strict demands on decency and industry were a salient, unquestionable part of children's practical lives in the war-time Finland.

\section{Method}

The purpose of this article is to describe how Finnish children were educated during the war time and how they perceive the hard period of their life. The following research questions were set for this study:

(1) How was elementary education arranged during the Second World War in Finland?

(2) How do Finnish war children describe their life during the war?

The first research question is discussed in the light of the archival sources while the second opens the life during the war years from the children's point of view. Thus, the data comprise former war-children's memories and supplementary research literature on elementary education during the war years. Thirteen children's of war were interviewed. In this study, 
they are referred with fictitious names: Ann (b. 1942), Brigitte (b. 1938), Elizabeth (b. 1936), Iris (b. 1940), Karen (b. 1937), Lena (b. 1941), Lisa (b. 1933), Matt (b. 1928), Oscar (b. 1938), Paul (b. 1933), Peter (b. 1935), Theresa (b. 1941), and Toby (b. 1940). All of them were from northern Finland, the province of Lapland. All of them were evacuated during the war and most of their parents served in front (fathers) or as lottas (lottas served in a Finnish voluntary auxiliary paramilitary organization for women). Some of them lost their parent or parents. In addition, some of their homes were destroyed during the war. The participants shared memories of becoming separated from their families as a child or being orphans who were sold to step-families, living in constant want, doing everything by themselves, and of diseases, interruptions to studies, hard work and effort, war-time scarcity, and discomfort - all these were part of their life (Purhonen et al., 2008). Although not all participants had experienced all these miseries, they shared a similar experiential world (Edmunds \& Turner, 2002; Manneheim, 1952; Purhonen et al., 2008).

The participants were interviewed personally and the interview method was theme interview (e.g., Hirsjärvi \& Hurme, 2001). Common features were looked for from the interview data. This study forms a part of a larger research that aims at constructing a holistic picture of war-time childhood: What is childhood like in war and what factors enhance coping with war?

Memory data make it possible to describe children's life during the war from their point of view. The interviewees reminisced, interpreted, and described their life (see Granfelt, 1998). The data can be seen as talk about the past. Retrospection means also remembering, sharing, contemplating, and situating one's life as a part of the history (Portelli, 2006). Naturally, research participants can select those events and issues that they want to share. They also can omit some aspects that they consider irrelevant, do not want talk about for some reason, or have simply forgotten (Silvasti, 2001).

Interviews were transcribed carefully and analyzed in the light of the pre-determined research questions. Therefore, the analysis method was qualitative content analysis (Mayring, 2000; Silverman, 2005). The interview data were supplemented by archival sources and carefully selected, relevant research literature of the time of Second World War in Finland. The archival sources included letter copies and minutes of teachers' meetings.

This study was a continuum to Dr. Merja Paksuniemi's (2009) doctoral research that focused on Finnish teacher training at the beginning of the $20^{\text {th }}$ century. The data were collected by Dr. Paksuniemi and analyzed in cooperation from this select point of view within the research group of Dr. Paksuniemi, Dr. Satu Uusiautti, and Prof. Kaarina Määttä. This study is a part of our studies on this educational-historical theme (Paksuniemi, Määttä, \& Uusiautti, 2012; Paksuniemi, Uusiautti, \& Määttä, 2012a,b,c) at the University of Lapland, Finland.

\section{Results}

\subsection{The Operation of Elementary Schools}

War time affected elementary education and were found extremely difficult by the schooling system. Education was provided anywhere possible depending on a situation (Kuikka, 2001). 


\section{MlMacrothink}

Journal of Studies in Education

ISSN 2162-6952

2013, Vol. 3, No. 1

The National Board of Education gave directions to elementary schools how they should arrange teaching in these exceptional circumstances (Da:2.). During the whole Winter War, education was non-uniform and irregular. When the peace came, the situation got a bit better but education was again interrupted due to the Continuation War (Paksuniemi, 2009). The teacher training school that operated with the teacher training college of Tornio provided teaching within the realms of possibility. Various buildings were rented from the city of Tornio for this purpose. (Ca:3; Da:2.) Similar special arrangements took place in other elementary schools of Finland and when the war was at its wildest the school system stopped totally (Nurmi, 1989; Hölsä, 2007).

During the Lapland War, the whole population of Lapland including their cattle was evacuated at least near the mid-Finland or in northern Sweden. War years, thus, had stronger effect in Lapland than in southern Finland. The number of children who went to school decreased because 70,000 children were sent as war children in other Nordic countries. The total number of war children was about a third of the school age children of Finland. A majority of the population of northern Finland was evacuated in Sweden, including also school age children. Several thousands of Finnish children stayed abroad permanently. (Kavén, 1985; 2010; 2011; Knuuttila \& Levola, 2000; Lagnebro, 1990; Räsänen, 1988; Salminen, 2007.)

The development plans for compulsory education were postponed in the 1930s because during the war years, the school authorities focused on organizing and securing elementary education (Hölsä, 2007). The strengthening of the new pedagogical trends was interrupted as Finland's connections to the rest of the world went off and so did the school reform (Paksuniemi, 2009).

Along the war the objectives of education changed and the significance of the national values and the Finnish history became emphasized (Hölsä, 2007). For example, the teacher training school that operated with the teacher training college of Tornio emphasized clearly the strengthening of Finnish national identity and nationalism (Hc:1). Partly, the change was due to the directions given by the National Board of Education and partly because of the circumstances of that time: patriotic spirit, national solidarity, and volition to defend one's country were cherished at school (Hölsä, 2007).

The aforementioned objectives were included in teaching of various subjects. In October 1941, the National Board of Education gave directions that schools should provide education in civil defense (Da:3). School children's physical shape was improved in PE lessons. Writings in Elementary School Journals instructed teachers how to include civil defense in physical education. For example, sufficient skiing skills were important for defense and therefore, physical education had to be provided with military punctuality in schools (e.g., Piironen, 1941). Excursions in the woods by foot and skiing were given primary importance along with downhill skiing and ball games. Scout running and orienteering were also considered important for defense education (Pihkala, 1930).

Regional education was supposed to ignite and deepen pupils' patriotic action. Christianity was also included in education. Journals in the field published writings that highlighted the 


\section{Mll Macrothink}

Finnish nationality and religion, and how to strengthen the national spirit during the war time. Teachers advised their colleagues with various examples on how to cherish Christianity: "morning and evening devotions are precious as they help children to cherish the reason for payers and gratitude to God for everything they face" (Teräs, 1945, p. 293).

Religious education also aimed at strengthening national spirit for example through learning patriotic hymns. The archival data describe quite carefully how lessons proceeded. For instance, one theme of a lesson of regional education was hands. Pupils were taught about all joints and bones of hands and at the end of the instruction they were asked: "You all have healthy hands. Who do you thank for it?" And as predicted, pupils answered "God". (Hc:1.) Several manuals of defense were published during the war years. They combine patriotism and defense as a part of physical education. The emphasis on nationalism was manifested in the insistence on knowing the Finnish soil and nature, the fathers' legacy, religion, the Finnish language, laws, and the Finnish literature and music. Likewise, national education was highlighted. (e.g., Arto, 1941; Rautavuori \& Karakoski, 1939; Valorinta, 1941; Nurmi, 1989). Also children's self-sacrifying effort for Finland was required: "Your life belongs to the fatherland" (Valorinta, 1941, p. 2).

Making with hands became significant during the war. Pupils participated in voluntary work for the nation. Indeed, people referred to school as work school because it taught necessary life skills (Nurmi, 1989). Soon, this kind of action was organized into systematic activity as the organization called the Youth's Voluntary Work was established. Pupils would participate in mushroom, berry, wood, and cone picking and do other useful work. Tasks were divided into four groups: picking, farm and manufacture work, general helping, and saving activity. In addition, activities included recreation, which meant for example youth camps and voluntary work celebrations (The Youth's Book of Work and Voluntary Work, 1944; Varjo, 1979). According to Syväoja (2007), voluntary work was practice-oriented patriotic and civic education. Finland was divided into voluntary work districts that were corresponding to elementary school districts. Children participated in voluntary work according to their age and skills.

\subsection{War Time from Children's Point of View}

The 1921 Act on Compulsory Education concerned all 7-12-year-old children and therefore, all participants of this research, too. As was described in the previous chapter, citizens were educated as well as possible even in the exceptional circumstances (Paksuniemi, 2009). The social political position of the Finnish elementary schools was accentuated during the war. The task of schools was to make children and the youth with defense skills. Teachers took care of the organization of voluntary work and did their share in increasing the welfare of the state and raising hard-working children. Matt remembered that patriotic acts were important during the war:

People did things together without pay for the common good. For example, pupils went to do voluntary work (small logs of wood) led by their teachers. No one questioned the work but "we were happy to do it. (Matt) 
According to the interviews, school going set the pace for the interviewees' life but war-time childhood also meant starting to bear one's responsibility. Children had to work because all men of working age were in the war. Country girls and boys started to work gradually after infancy: at the age of 5 or 6 , many families started to teach children how to work. Approximately at the age of 10-14, boys were big enough to do men's work and girls were expected to do women's duties. Children grew into adults by working. Although at some periods during the war, school attendance remained minimal (Tuomaala, 2008), the 1921 act did, however, guarantee general right and civil duty to study.

Work and school filled war children's lives. Oscar told how he and his grandfather had to do men's work at home:

I had to work before going to school. I woke up at five a.m. in the morning to work in the cowhouse with my granny. In the winter, I had to take my sleigh and get tubful of snow that was melted in a pot to be drinking water for cows. Of course, I had to light up the stove. I had to spend evenings in the cowhouse too and during weekends, my grandpa and I, we would pick up firewood. In the summer, we would make hay for the cattle. (Oscar)

According to the interviews, adults were busy during the war and reconstruction years and they did not have much time to spend with children. Oscar told that his life was filled with daily chores:

I had to cook and do laundry. It was alright in the summer when you could do it on the beach. We had sheep, reindeer, a horse, cows, and calves. I was busy with them. (Oscar)

No one had time to watch children. They just would run around there. Parents would work. Children kept company to each other. (Lena)

Theresa had noticed the following: "I had the feeling that I won't cope in life until I learn to work." According to the interviewees, children had to do household work but also work outside home (Ann, Karen, Lena, Matt, Oscar, and Theresa). Simultaneously as the themes of solidarity and diligent citizenship were emphasized at school, children learned them in practice in their private lives too. According to the interviewees' stories, the war-time circumstances in childhood and the obligation to work had affected their lives. Lena said:

War-time conditions taught that life is not just a game. We learned to work, be persevering and responsible. (Lena)

Oscar also highlighted tolerance:

I had to work and others' help was really important. As adult, I have cherished this kind of tolerance and helping and minding others. (Oscar)

Doing one's share for the nation and helping fellow humans were part of children's everyday life at school and at home, and according to the interviewees, were internalized at an early point of life. Children went to school and did the household work they could. Handicraft skills were taught at school to help coping with scarcity and to teach citizens to be 
self-sufficient, economical, and useful. Indeed, being able to do with hands was important in children's lives and these skills were useful in practice.

Lisa talked about her countryside school where a soldier who had returned from the front worked as a teacher. The man had been wounded and could not go back to the front. He taught at the school and his wife taught handicraft. Neither of them were qualified teachers.

And I remember when I was supposed to cut a hole in the cloth, to have a button hole, and so I cut a round hole. And the teacher yelled like crazy, I had not heard yelling like that in my life, because I had totally ruined the material. (Lisa)

During the war, there was lack of materials. Lisa thought that she had deserved the teacher's reproof. She still was irked because she had misunderstood the instruction and ruined the material. In addition, Lisa remembered that lottas' base was near to their school. Lottas taught them how to do practical handicrafts, such as how to darn socks and patch clothes. During the war time, order was maintained in schools through strict discipline. Therefore, Lisa being reprehended by her teacher was not unprecedented but quite common (Valta, 2002).

Children used their skills in leisure, too. For example, Karen told:

Of course, whenever possible, we went to play. We would make dolls of rags because we did not have any material. We would play with cone cows and of course, hide-and-seek and tag. (Karen)

Ann's memories showed the same:

We would make cows of cones and put them out to pasture to eat. (Ann)

Theresa had played house and the necessary equipment was found in the neighborhood:

The neighborhood where we lived had had horrible battles. There was that junk for sure.

I lugged a chunk of iron to be a stove. I did not know that was a support frame for a mine. (Theresa)

There was a lack of everything during the war (e.g., Paksuniemi, 2009), including toys. If children needed toys, they would prepare them by themselves, for example stilts for walking on stilts and shop play where three leaves functioned as money. Ann continued:

We made a rag doll because we did not have any dolls bought from a shop. (Ann)

There was lack of food, too. The interviewees remembered (Ann , Brigitte, Elizabeth, Iris, Karen, Lena, Matt, Paul, Peter, Theresa, and Toby) how the scanty food was divided and counted carefully at home to make it suffice as many days as possible. Lisa told how her aunt made her a sandwich to take with her at school. However, Lisa noticed that one of her friends did not have any food and Lisa asked her aunt to make two sandwiches. She would give the other to her friend. In 1943, the school had a hut where they started to prepare meals. Lisa remembered:

And my aunt wondered why I did not gain weight although I had all these sandwiches! [At the school dining hut], they were really careful who was allowed to have the meal. I 
had it only once when I did not have the packed lunch with me but this friend of mine had meal almost every day. (Lisa)

According to the interviewees (Brigitte, Elizabeth, Iris, Karen, Lisa, Matt, Paul), they played the Finnish baseball during PE lessons when there was no snow. The equipment for the game were relatively affordable compared to for example skis. According to Vasara (1997), baseball playing was a sport that supported defense. It developed skills that are needed in the front: throwing and fast running. In addition, it taught discipline and initiative. Quite soon after snow came, elementary school PE lessons included skiing. Paul's home was located on the opposite shore from the school. He would come to school by rowing a boat when there was no ice, walked at the time of frost heave, and skied in the winter.

I remember that too when the snow would stick to the bottom of my skis and when I finally arrived at school I had inches thick lumps of snow under my skis. And of course, it was dark when I skied over the lake. I put my skis in the porch of the school to melt. So, I skied a lot because we would also ski in the PE lessons! I sure was tried when I finally got home! (Paul)

Iris's family could not afford to buy skis and so her teacher lent skis to her:

And the teacher lent the teacher's child's skis and the skis were painted into yellow. I was so embarrassed when everyone saw those garish yellow skis and now they were the teacher's child's pair and that we did not have money to buy own skis. (Iris)

Pupils skid in the nearby country and how to move there. This was an important skill for defense in case of a possible assault (Vasara, 1997). The importance of skiing was emphasized in the Finnish teachers' journal already before the war had started:

In the winter, you have an excellent chance to take children to ski on the white snow and let them ski as much as they please. Every muscle get exercised, they gain more muscular strength. For the defense, it is extremely important to teach skiing already in primary schools. (Tuomisto, 1933, p. 170)

As the purpose was to build the common Finland, patriotic teachers considered they are obliged to enlighten and educate other teachers.

Despite the childhood lived under the war-time circumstances, Ann, Brigitte, Elizabeth, Iris, Karen, Lena, Lisa, Matt, Oscar, Paul, Peter, Theresa, and Toby had survived well. They left the countryside quite early to work in bigger population centers, and some of them returned their places of domicile, some stayed in cities. Everyone graduated in a profession and started a family. Two became teachers, one as a forest engineer, two started their own businesses, and two ended in nursing professions. Remaining six interviewees worked as self-employed persons, such as farmers.

\section{Discussion}

War years slowed down the development of elementary education considerably. Connection to the outer world was cut off and educational trends, for example reform pedagogy from 
Estonia, took the back seat. Order and discipline were preferred at school but also socialization. The war years introduced a new situation to the whole school system. In some parts of Finland, education continued but was interrupted in other parts because school buildings served as accommodation and war hospitals. The war time affected teaching in elementary schools because it had the mission for the common nation, Finland. Although education was arranged irregularly during the war time, one very significant change took place when the law on providing free school dining took effect in 1943. It was to secure children's physical shape. The law included a five-year transitional period but the law was followed in some places regardless of the depression (Nurmi, 1989; Virta, 2001). The idea behind the law was to secure citizens' well-being at the time when there was lack of everything, including food.

As the results showed, children had similar experiences that represent a common experiential world. Because of the war, children had to do adults' work more than they would have had to during non-war time, along with their studies. Responsibilities filled their childhood. However, children did not think work unpleasant as it was taken for granted that they had to work. Some of them wanted to learn adults' work because it meant survival in life (see also Näre \& Kirves, 2007; Tuomaala, 2008).

Children also learned to help and share with others for the common good. Honkasalo (2000) had also pointed out that although the war caused fear, suffering, and broken dreams, it also gave birth to communality among Finns which was emphasized both at school and homes (see also Näre \& Kirves, 2007). Although work and school had set the pace to the participants' lives, they played whenever possible but the scarcity and lack of material was the reality: children were taught to be economical (see Kemppainen, 2006; Nevala-Nurmi, 2006; Pukkila, 2008; Tepora, 2007; Tuominen, 2005).

Due to the emotional, physical, and economic insecurity that the war years brought into children's lives (Jensen \& Shaw, 1993; Kemppainen, 2006; Latvala, 2006; Loughry \& Eyber, 2003; Salminen, 2006), school and all activity that took place in schools provided order in children's irregular life. This study showed how the war time set clear demands on how children should act and behave. They were expected to work hard and help regardless of fear, losses, and drastic changes in their family life. This was also because of the common attitude in the contemporary Finland as the young nation was just constructing its nationhood (Anttonen, 1998). Schooling and school systems have proved repeatedly to be key devices for the development and transmission of a sense of nationhood, or national identity, and education system has been used as an important agency for defining precisely what form that shared sense should take (Lowe, 1999). According to Field (1994), both the content and structure of classrooms were changed to foster patriotism, community service, interest in geography and history, and good citizenship traits.

When it comes to the interviews, we cannot be certain of the accuracy of the participants' memories. However, we can be completely sure that they were children during the war time and had experienced the war which made them eligible to talk about their experiences in this study. Memories are experientially true to the one who remembers them (Passerini, 1989; 
Portelli, 2006). Thus, the researchers must be humble when obtaining the data, concludes Leskelä-Kärki (2001). We can reach the past in a way the people actually experienced it. Instead, memories reveal what are those events and experiences people find worth remembering, sharing, and maintaining, and how they reminisce, interpret, and produce their own histories.

Furthermore, Reinhart Koselleck (1992) has analyzed war experiences and features that mold the consciousness of war and concludes how the direct experiences of war involve consciousness that covers many dimensions: these are for example belonging to a certain linguistic society; religious, world view, and ideological ideas; belonging to a political party; gender, family background, and social, professional, and residential status. War experiences become memories through a constant process in which the experiences are forgotten, remembered, evaluated, renewed, and molded (Koselleck, 1992). Along the process, experiences and memories become stratified and integrated in new kinds of combinations. Therefore, memories as a research target have been taken with suspicious (Portelli, 2006) because a memory represents one person's perception and comes up after the events. A human memory can twist, add, prettify, forget, and deliberately omit happenings. It was not until the 1980s when historical research started to use memories (Ukkonen, 2002).

In this study, the interviewees' memories complement the archival data in a rich manner providing a vivid picture of the war-time childhood and education. The interview data also showed how the themes emphasized in the curricula, regulations, and meetings were realized in practice and how they appeared in children's lives. In a study like this one, we are forced to contend with multiple identities and multiple memories (Gillis 1994). Grosvenor (1999) problematizes the interpretation of the past and nationality by saying:

Thus, 'our' sense of 'our' past and 'our' ability to comprehend 'our' future appear increasingly uncertain. In short, 'we' are in an age where 'we' are less certain about who 'we' are (p. 240).

\section{Conclusion}

Children and their education across the world were affected by the war (see e.g., Bonte \& Musgorve, 1943; Cunningham \& Gardner, 1999; Tuttle, Jr., 1993). According to Ichino and Winter-Ebner (1999), European countries involved in World War II, children who were ten years old during the conflict were significantly less likely to proceed into higher education. And it was only after the World War II when elementary education started to expand in many countries (see e.g., Benavot \& Riddle, 1988; Simkus \& Andorka, 1982; Sutherland, 1986).

Indeed, war-time and post-war education were also seen as an important means to enhance national spirit among citizens (Cuban, 1993; Grosvenor, 1999). Even today, school history traditionally has been regarded as the primary place in the school curriculum for students to cultivate a sense of national identity and heritage (Foster, 1999). The emphasis on home land, the national home, is crucial. For instance, Grosvenor (1999, p. 242) lists how much the word 'home' is rich in associations: Home sweet home, home is where the heart is, make yourself at home, there's no place like home, etc. War-time education was to lift up the national spirit 
and provide with defense skills. Teachers were expected to be moral leaders and David Limond (2000) has pointed out that the move from moral to morale is brief and describes the war-time situation and the teachers' role in it.

The same concerned Finland, too. As the war years ended in 1945, a new society had to be built in a situation where the direction was defined outside the country. Although peace concluded, the war affected the life of the Finnish society and peoplle for a long time (Virrankoski, 1975; Jokipii, 1987). After the wars, the developmental plans for elementary education were continued again, and indeed, several suggestions for the renewal of educational system were made (Paksuniemi, 2009). At that time, Finland was strongly agrarian and most of the Finns lived in the countryside. Therefore, it was considered relevant to change the curricula of countryside schools as the purpose was to educate the whole nation (Isosaari, 1973). Moreover, welfare was not just considered provision by the state but also what people can do for each other, the goal was active, patriotic citizenship in all education (see also Campbell, 2008; Milligan, Morretti, \& Oreopoulos, 2004; Määttä \& Paksuniemi, 2011).

During the war years, the national spirit became a salient part of education in Finnish schools. Children were raised to Christianity, diligence, and dutifulness: to be citizens who serve the Finnish nation. This ideology had a strong basis already in the 1920s when the school system was built to serve the independent nation. The educational ideal was a moral-Christian pupil. Lutheranism emphasized willingness to be of service and obedience of authorities. Citizens were considered the hope of the fatherland (Koski, 2001). Citizenship was thematized in terms of education and enlightened citizens and it included a strong moral commitment to the welfare of the whole nation (Anttonen, 1998; Satka, 1995). At the individual level, war children represented the generation of structural changes and increasing educational possibilities in Finland (1936-1955). Along the development, education was started to see as means of personal growth and career development. Due to the active development of elementary education and rapid industrialization of the Finnish society, the next generation (b. 1956 - ) could already perceive education and welfare as obviousness. (Roos, 1987). A famous educational-sociologist J. P. Roos (1987) points out that education has a clear and interesting effect in biographies. Likewise, this study showed the interconnectedness of the war-time educational system and national interests toward its development with the war children's personal experiences.

\section{References}

Act on Compulsory Education. (1921). Helsinki: Ministry of Justice.

Anttonen, A. (1998). Vocabularies of citizenship and gender: Finland. Critical Social Policy, 18, 355-373. http://dx.doi.org/10.1177/026101839801805605

Arto, E. (1941). Maanpuolustustietoa koululaisille. Oppikouluja ja seminaareja varten [Information about defense for pupils. For secondary schools and colleges]. Helsinki: Otava.

Benavot, A., \& Riddle, P. (1988). The expansion of primary education, 1870-1940: Trends and issues. Sociology of Education, 61(3), 191-210. 


\section{Macrothink}

Journal of Studies in Education

ISSN 2162-6952

2013, Vol. 3, No. 1

Bonte, P., \& Musgorve, M. (1943). Influences of war as evidenced in children's play. Child Development, 14(4), 179-200.

Campbell, D. (2008). Voice in the classroom: how an open classroom climate fosters political engagement among adolescents. Political Behavior, 30(4), 437-454.

Cuban, L. (1993). How teachers taught: Constancy and change in American Classrooms, 1800-1900. New York, NY: Teachers College Press.

Cunningham, P., \& Gardner, P. (1999)."'Saving the nation's children": teachers, wartime evacuation in England and Wales and the construction of national identity. History of Education, 28(3), 327-337.

Field, S. L. (1994). Scrap drives, stamp sales, and school spirit: examples of elementary social studies during World War II. Theory \& Research in Social Education, 22(4), 441-460. http://dx.doi.org/10.1080/00933104.1994.10505734

Foster, S. J. (1999). The struggle for American identity: treatment of ethnic groups in United States history textbooks. History of Education, 28(3), 251-278.

Gillis, J. R. (1994). Memory and identity: the history of a relationship. In R. J. Gillis (Ed.), Commemorations. The politics of national identity (pp. 15-16). Princeton, NJ: Princeton University Press.

Grosvenor, I. (1999). 'There's no place like home': education and the making of national identity. History of Education, 28(3), 235-250.

Häikiö, M., (1996). Suomi toisessa maailmansodassa [Finland in the Second World War]. In A. Korppi-Tommola (Ed.), Sotalapset. Tutkimusraportti [War children. A research report] (pp. 4-7). Helsinki: Mannerheimin lastensuojeluliitto.

Heikkinen, R. (1995). Kasvatus ja koulutus Kainuussa. Kainuun koulutusjärjestelmän kehitys syyskuuhun 1945 mennessä [Education in Kainuu. The development of Kainuu education system by 1945]. Kajaani: Teacher Training Department of Kajaani, University of Oulu.

Hirsjärvi, S., \& Hurme, H. (2001). Tutkimushaastattelu - Teemahaastattelun teoria ja käytäntö [Research interview -The theory and practice of theme interview]. Helsinki: Helsinki University Press.

Hölsä, M. (2007). Sotavuodet ja koulunkäynti [War years and schooling]. In Koululaitos itsenäisen Suomen rakentajana. Suomen kouluhistoriallisen seuran vuosikirja [The school system as the builder of independent Finland. The annual of The Finnish Society for the History of Education] (pp. 46-74). Helsinki: The Finnish Society for the History of Education.

Honkasalo, M. (2000). Suomalainen sotainvalidi [A Finnish disabled veteran of war]. Helsinki: Otava.

Hopkins, E. (1989). Elementary education in Birmingham during the Second World War. History of Education: Journal of the History of Education Society, 18(3), 243-255. 
http://dx.doi.org/10.1080/0046760890180305

Hyyrö, T. (2000). Kaurialan kassapäät vuosina 1940-1945. Suistamon ja Hämeenlinnan alakansakouluseminaarien yhteiset vuodet Hämeenlinnassa [The students of Kauriala in 1940-1945. Common years of Suistamo and Hämeenlinna primary education teacher training colleges in Hämeenlinna]. In Kasvatus ja koulutus murrosaikoina. Suomen koulutushistoriallisen seuran vuosikirja [Education and schooling in transition periods. The annual of the Finnish educational historical society]. Vantaa: Tummavuoren kirjapaino Oy.

Ichino, A., \& Winter-Ebmer, R. (1999). The long-run educational cost of World War II. An example of local average treatment effect estimation. [Online] Available: http://www.etla.fi/PURE/war22.pdf (December 7, 2012)

Isosaari, J. (1973). Suomen koululaitoksen rakenne ja kehitys [The structure and development of the Finnish school system]. Keuruu: Otava.

Jensen, P. S., \& Shaw, J. (1993). Children as victims of war: current knowledge and future research needs. Journal of the American Academy of Child \& Adolescent Psychiatry, 32(4), 697-708.

Jokipii, M. (1987). Jatkosodan synty. Tutkimuksia Saksan ja Suomen sotilaallisesta yhteistyöstä 1940-1941 [The birth of Winter War. Studies of the military cooperation between Germany and Finland]. Helsinki: Otava.

Kavén, P. (1985). 70000 Pientä kohtaloa [70,000 little fates]. Keuruu: Otava.

Kavén, P. (2010). Humanitaarisuuden varjossa. Poliittiset tekijät lastensiirroissa Ruotsiin sotiemme aikana ja niiden jälkeen [In the shadow of humanitarity. Political factors in child evacuation to Sweden during the wars and after them]. Helsinki: University of Helsinki.

Kavén, P. (2011). Sotalapset, toiveet ja todellisuus [War children, hopes, and reality]. Helsinki: Minerva.

Kemppainen, I. (2006). Isät, äidit ja isänmaan toivot - käsityksiä lapsista ja vanhemmista sotavuosien Suomessa [Fathers, mothers, and the hopes of the fatherland-conceptions of children and parents in the war-time Finland]. Historiallinen aikakauskirja [Historical Journal], 2, 163-173.

Knuuttila, J., \& Levola, K. (2000). Sotalapsi ei unohda [A war child does not forget]. Helsinki: Tammi.

Korppi-Tommola, A. (Ed.) (1996). Sotalapset: Mannerheimin Lastensuojeluliiton tutkimusraportti [War children: A research report of the Mannerheim League for Child Welfare]. Helsinki: Mannerheim League for Child Welfare.

Koselleck, E. (1992). Der Einfluss der beiden Weltkriege auf das soziale Bewusstsein [The influence of both World Wars in the social conscience]. In H. Wette (Ed.), Der Krieg des Kleinen Mannes. Eine Militärgeschichte von unten [A little man's war. A soldier's story from the grassroot level] (pp. 324-333). München: Grim. 
Koski, L. (2001). Hyvän lapsen ja kasvattamisen ideaalit. Tutkimus aapisten moraalisen kosmologian muutoksista itsenäisyyden aikana [The ideals of a good child and education. A study of the changes in moral cosmology in $A B C$ books after Finland gained its independency]. Turku: Finnish Educational Research Association.

Kuikka, M. T. (2001). Kansanopetuksen suuret linjat [The general guidelines of folk education]. In Koko kansan koulu. Suomen kouluhistoriallisen seuran vuosikirja The whole nation's school. Annual of The Finnish Society for the History of Education] (pp. 152-182). Helsinki: The Finnish Society for the History of Education.

Lagnebro, L. (1990). Finska krigsbarn-en kvalitativ studie [Finnish war chilren - a qualitative study]. Siirtolaisuus-Migration, 2/1990.

Latvala, P. (2006). Lapsuuteeni kuuluivat sota, siirtolaiset ja sankarihautajaiset [The war, migrants and heroic funerals belonged to my childhood]. Historiallinen aikakauskirja [The Historical Journal], 2, 142-152.

Leskelä-Kärki, M. (2001). Kerrottu elämä. Naishistorioitsija ja toisen ihmisen historian kirjoittamisen ongelma [Narrated life. A woman historian and the problem of writing another people's story]. In J. Kalela, \& I. Lindroos (Eds.), Jokapäiväinen historia [Daily history] (pp. 98-120). Helsinki: Finnish Literature Association.

Limon, D. (2000). Only talk in the staffroom: 'suberversive' teaching in a Scottish school, 1939-40. History of Education, 29 (3), 239-252.

Loughry, M. \& Eyber, C. (2003). Psychosocial concepts in humanitarian work with children: a review of the concepts and related literature. Washington, D.C.: National Academies Press.

Lowe, R. (1999). Education and national identity. History of Education, 28(3), 231-233.

Määttä, K., \& Paksuniemi, M. (2011). At the roots of the pedagogy of Finnish teacher training: Practicum as a core of teacher training in Teacher College of Tornio in the 1920s. International Journal of Educational Administration and Policy Studies, 3(8), 121-128.

Manneheim, K. (1952). The problem of generations. In K. Manneheim (Ed.), Essays on the sociology of knowledge (pp. 276-322). London: Routledge \& Kegan Paul.

Mayring, P. (2000). Qualitative content analysis. Qualitative Social Research, 1(2). [Online] Available: http://www.qualitative-research.net/index.php/fqs/article/view/1089/2386 (October 2, 2012).

Milligan, K. S., Moretti, E., \& Oreopoulos, P. (2004). Does education improve citizenship? Evidence from the U.S. and the U.K. Journal of Public Economics, 88(9-10), 1667-1695.

Municipal Archives of Oulu:

Näre, S., \& Kirves, J. (2007). Lapsuus sodan keskellä [Childhood in the middle of the war]. In Sodassa koettua, haavoitettu lapsuus [Experienced at wor, wounded childhood] (pp. 8-29). Porvoo: Weilin + Göös. 


\section{Macrothink}

Journal of Studies in Education

ISSN 2162-6952

2013, Vol. 3, No. 1

Nevala-Nurmi, S.-L. (2006). Nuoria maan puolustajia vai suomalaisia lapsisotilaita? [Young national defenders or Finnish child soldiers?] Historiallinen aikakauskirja [The Historical Journal], 2, 153-162.

Nuorten työ- ja talkookirja [The Youth's Book of Work and Voluntary Work]. (1944). Helsinki: Nuorten Talkoot.

Nurmi, V. (1989). Kansakoulusta peruskouluun [From elementary school to comprehensive school]. Juva: Wsoy.

Nurmi, V. (1995). Suomen kansakoulunopettajaseminaarien historia [The history of Finnish teacher training colleges]. Helsinki: OAJ.

Päivänsalo, P. (1971). Kasvatuksen historian tutkimus Suomessa vuoteen 1970 [The educational historical research in Finland until 1970]. Helsinki: Ylioppilastuki ry.

Paksuniemi, M. (2009). Tornion alakansakoulunopettajaseminaarin opettajakuva lukuvuosina 1921-1945 rajautuen oppilasvalintoihin, oppikirjoihin ja oheistoimintaan [The teacher image in the lower primary school teachers' college of Tornio in 1921-1945 in the light of selection of students, textbooks, and activities of leisure time]. $\mathrm{PhD}$ diss., University of Lapland, Rovaniemi, Finland.

Paksuniemi, M., Määttä, K., \& Uusiautti, S. (2012). Childhood in the shadow of war: filled with work and play. Children's Geographies, in press.

Paksuniemi, M., Uusiautti, S., \& Määttä, K. (2012a). From teachers into multiply skilled persons: How was art education implemented at a Finnish teacher training college in 1921-1970? International Journal of Research Studies in Education, online First. doi: $10.5861 /$ ijrse.2012.143

Paksuniemi, M., Uusiautti, S., \& Määttä, K. (2012b). Teetotalism as the core of education at the elementary school teacher training college of Tornio, Finland. History of Education \& Children's Literature, 7(1), 389-411.

Paksuniemi, M., Uusiautti, S., \& Määttä, K. (2012c). Teacher education in Finland during the war years 1939-1945. War \& Society, 33(1), in press.

Passerini, L. (1989). Women's personal narratives: myths, experiences, and emotions. In Personal Narrative Group (Eds.), Interpreting women's lives (pp. 189-197). Bloomington, IN: Indiana University Press.

Pihkala, L. (1930). Koulumme ja puolustuskunto [Our schools and level of defense]. In Suur-Suomen koulu [The Great Finland’s school]. Jyväskylä: Gummerus.

Piironen, M. (1941). Isänmaallisuuden kasvattaminen alakansakouluissa [Boosting patriotism in primary schools]. Alakansakoulu [Primary School Journal], 14, 219-225.

Portelli, A. (2006). Mikä tekee muistitietotutkimuksesta erityisen? [What makes memoirs research special?] In O. Fingeroos, R. Haanpää, A. Heimo, \& U.-M. Peltonen (Eds.), Muistitietotutkimus. Metodologisia kysymyksiä [Memoirs research. Methodologival questions] 
(pp. 49-64). Helsinki: Finnish Literature Association.

Pukkila, H. (2008). Kotirintaman lapset [Children of the home front]. Helsinki: Tammi.

Purhonen, S., Hikkala, T., \& Roos, J. P. (2008). Suuret ikäluokat ja elämän käännekohdat [Great generations and turning points of life]. In S. Purhonen, T. Hoikkala, \& J. P. Roos (Eds.), Kenen sukupolveen kuulut? Suurten ikäluokkien tarina [Whose generation do you belong to? The story of great generations] (pp. 33-50). Tampere: Esa Print.

Räsänen, E. (1988). Lapsuusajan separaatiokokemusten vaikutus aikuisiän psyykkiseen ja fyysiseen terveyteen sekä sosiaaliseen hyvinvointiin. Psykososiaalinen tutkimus sotalapsiseparaation myöhäisvaikutuksista [The influence of childhood separation experiances in adulthood mental and physical health and social well-being. A psycho-social study of later effects of war child separation]. Kuopio: University of Kuopio.

Rautavuori, M., \& Karakoski, K. (1939). Maanpuolustus. Maanpuolustusıpetuksen käsikirja [Defense. Manual of defense education]. Helsinki: WSOY.

Rinne, M. (1973). Suomen opettajain Liitto 1893-1973 [The Finnish Teacher Union 1893-1973]. Vammala: Vammalan Kirjapaino Oy.

Roos, J. P. (1987). Suomalainen elämä - Tutkimus tavallisten suomalaisten elämäkerroista [Finnish life - A study of ordinary Finns' biographies]. Hämeenlinna: Finnish Literature Association.

Salmi, T. (1986). Kansakunnan lesket. Raportti suomalaisista naisista jotka menettivät miehensä toisen maailmansodan vuoksi [Nation's widows. A report of Finnish women who lost their husbands because of the Second World War]. Helsinki: Tammi.

Salminen, H. (2006). Lapset sodankäynnin uhreina. Sotalapset ja lastensiirrot 1900-luvulla [Children as victims of war. War children and child evacuations in the 20th century]. Historiallinen aikakauskirja [Historical Journal], 2, 132-141.

Salminen, H. (2007). Lappu kaulassa yli Pohjanlahden. Suomalaisten sotalasten historia [A note on your neck over the Gulf of Bothnia. The history of FInnish war childre]. Turku: Institute of Migration.

Satka, M. (1995). Making social citizenship: conceptual practices from the Finnish poor law to professional social work. Jyväskylä. University of Jyväskylä.

Silvasti, T. (2001). Talonpojan elämä. Tutkimus elämäntapaa jäsentävistä kulttuurisista malleista [A farmer's life. A research on cultural models that structure life style]. Helsinki: Finnish Literature Association.

Silverman, D. (2005). Doing qualitative research, practical handbook. London: Sage.

Simkus, A., \& Andorka, R. (1982). Inequalities in educational attainment in Hungary, 1923-1973. American Sociological Review, 47(6), 740-751.

Sutherland, N. (1986). The triumph of "Formalism": Elementary schooling in Vancouver 
from the 1920s to the 1960s. BG Studies, 69-70, 175-210.

Tepora, T. (2007). Sota-ajan leikit ja koulu [War-time games and school]. In Sodassa koettua, haavoitettu lapsuus [Experienced in war, wounded childhood] (pp. 31-67). Porvoo: Weilin + Göös.

Teräs, H. (1945). Kristillisen hengen vaaliminen alakansakoulussa [Cherishing Christianity in primary schools]. Alakansakoulu [Primary School Journal], 14, 215-218.

Tuomaala, R. (2008). "Kyllähän nyt pitäs olla jo semmonen aika, että pääsis niin kö keskustelemhan näistä asioista.” Tutkimus lappilaisten huutolaisten, sotavankien ja partisaanien uhrien elämänkulusta, voimavaroista, terveydestä ja sairauksista ["It should already be time to talk about these things" A research on Lapp orphans, POWs, and victims of partisans courses of life, resources, health and diseases]. Turku: University of Turku.

Tuominen, L. K. (Ed.) (2005). Sotaorpojen ja sotalasten kokemuksia [War orphans'and war children's experiences]. Raisio: Newprint.

Tuomisto, A. (1933). Leikin, voimistelun ja urheilun merkitys alakansakouluissa sekä niiden rinnastus ympäristöopetukseen [The meaning of play, gymnastics, and sport in primary schools and integrating them to environmental education]. Alakansakoulu [Primary School Journal], 17, 169-171.

Tuttle Jr., W. M. (1995). "Daddy's gone to war": The Second World War in the lives of America's children. Oxford, NY: Oxford University Press.

Ukkonen, T. (2002). Menneisyyden tulkinta kertomalla. Muistelupuhe oman historian ja kokemuskertomusten tuottamisprosessina [Interpreting the past through narratives. Memories as the process of producing one's own history and stories about experiences]. Helsinki: Finnish Literature Association.

Valorinta, V. (1941). Pieni maanpuolustaja. Kansakoulunoppilaan ohjekirja [The little defender. Manual to elementary school pupils]. Helsinki: Otava.

Valta, J. (2002). Ongelmaoppilaat Oulun kansakoulussa vuosina 1874-1974 [Problem students at the Oulu elementary school 1874-1974]. PhD. diss. University of Oulu, Oulu, Finland.

Varjo, K. (1979). Nuorten talkoot. Suomen nuorison työliike 1940-1948 [The youth's voluntary wok. The work movement of the Finnish youth 1940-1948]. Helsinki: Finland's Cultural Foundation.

Vasara, E. (1997). Valkoisen Suomen urheilevat soturit. Suojeluskuntajärjestön urheilu- ja kasvatustoiminta vuosina 1918-1939 [The sportive warriors of the White Finland. The sport and educational activity of the Civil Guard Organization in 1918-1939]. Vammala: Vammalan kirjapaino Oy.

Virrankoski, P. (1975). Suomen taloushistoria kivikaudesta atomiaikaan [The economic history of Finland from the stone age to atomic age]. Helsinki: Otava. 


\section{Macrothink}

Journal of Studies in Education

ISSN 2162-6952 2013, Vol. 3, No. 1

Virta, I. (2001). Siirtoväen kansakoulukysymys sotavuosien Suomessa [The elementary education question of the immigrant population in war-time Finland]. Turku: University of Turku.

Wright, P. (1985). On living in an old country. The national past in contemporary Britain. London: Verso.

\section{Archival Sources:}

Municipal Archives of Oulu:

Ca:3. The proceedings of teachers' meetings 1936-1945.

Da:2. Copies of the letters 1929-1940.

Da:3. Copies of the letters 1941-1953.

Hc:1. Minutes of the evaluation meetings of teachers' practicum lessons 1941-1966.

\section{Copyright Disclaimer}

Copyright reserved by the author(s).

This article is an open-access article distributed under the terms and conditions of the Creative Commons Attribution license (http://creativecommons.org/licenses/by/3.0/). 